\title{
张家口地区排污工业企业集聚与 水污染空间耦合特征
}

\author{
于 慧 ${ }^{1}$,仲 佳 ${ }^{1,2}$, 刘邵权 ${ }^{1}$,杨德伟 ${ }^{3,4}$
}

(1. 中国科学院水利部成都山地灾害与环境研究所,成都 $610041 ; 2$. 中国科学院大学, 北京 100049 ;

3. 西南大学地理科学学院,重庆 $400715 ; 4$. 中国科学院城市环境研究所, 厦门 361021)

\begin{abstract}
摘要: 基于排污企业污染源环境统计数据, 应用水污染物排放强度和核密度分析等方法, 研究 张家口地区排污工业企业的空间集聚特征及其与水污染排放空间之间的空间耦合特征, 结果 显示: (1)张家口地区工业企业空间集聚程度存在一定的空间异质性, 崇礼县、赤城县整体上几 乎无污染密集型企业分布。污染密集型企业主要沿洋河流域分布。(2)农副食品加工业、黑色 金属冶炼及压延加工业、食品制造业、煤炭开采和选洗业这四大行业的 $\mathrm{COD} 、 \mathrm{NH}_{3}-\mathrm{N}$ 、总氮等水 体污染物排放量相对最大。(3)工业企业集聚度与水环境污染程度的空间正向耦合效应明显, $96.23 \%$ 的区域呈较强正向耦合特征。高集聚一污染高值区占比 $0.40 \%$ 。针对四种空间耦合状 态提出未来污染物排放管控方向,以期为政府部门准确锁定治理区提供决策依据。
\end{abstract}

关键词：排污工业企业集聚;水污染;空间耦合特征

产业集聚是指特定区域内关系密切的企业和机构，通过空间集聚发挥规模效应、集 聚效应，从而产生竞争优势 ${ }^{[1-3]}$ 。产业集聚对经济发展具有重要的促进作用 ${ }^{[4]}$ 。通过产业聚 集区来拉动经济增长是各地产业政策取向 ${ }^{[5]}$ 。国内外研究者在产业集聚与污染物排放及其 对环境污染方面进行深人研究 ${ }^{[6-12]}$ 。目前大量研究证实, 产业集聚对环境污染排放影响具 有多重性，两者既有正向作用、负向作用，也有交互耦合作用。一方面，产业集聚加快 区域产业竞争力、提升企业生产效率 ${ }^{[13,14]}$, 。当行业过度集聚并超过环境可以承载的限度

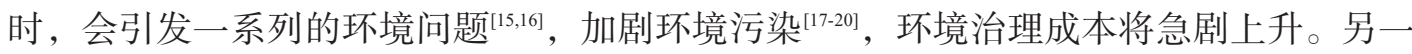
方面，废水污染型产业集聚有利于发挥污染治理的规模效应，降低污染。而废气/固废污 染型产业集聚则产生相反效应 ${ }^{[21]}$ 。通常，在产业集聚初始阶段，集聚区内污染物的排放 量将相应增加，但是随着集聚区的发展，资源集约利用、环境污染集中治理，排污总量 控制、产业排污行为的约束，污染排放量会逐步降低 ${ }^{[22,23]}$ 。因而，集聚发展往往都是被鼓 励的 ${ }^{[24]}$ 。同时，也需进一步推动集聚区内产业的技术改进提高企业的生产效率，减少污 染物排放强度，达到节能减排的效果，进而缓解环境污染。

通常使用相关性、多元回归等分析手段，研究产业集聚的响应过程 ${ }^{[12]}$, 而较少分析 产业集聚和水环境两者的空间耦合关系。研究多集中在东部沿海、长江经济带 ${ }^{[11,12,24]}$ 。作 为 2022 年冬季奥林匹克运动会的举办地之一，张家口的水环境质量保障任务紧迫。而排

收稿日期：2019-07-24；修订日期：2019-12-03

基金项目：国家水体污染控制与治理科技重大专项（2017ZX07101001）；国家自然科学基金项目（41671529， $41971273)$ ；长江经济带战略环境评价四川省 “三线一单” 编制资源利用上线划定（Y8D2600600）

作者简介：于慧 (1980-), 女, 山东烟台人, 博士, 副研究员, 研究方向为资源环境承载力与山区发展规划。 E-mail: yuhui@imde.ac.cn 
污企业过于集中，会造成环境风险增大。因此，如何科学建立张家口排污企业和水环境 的空间耦合关系，有效确定工业污染物排放热区，识别水污染防治的重点管控区，成为 函待解决的科学问题。本文以张家口地区为案例区，以 2017 年各行业企业的空间分布数 据和排污数据为基础, 研究排污工业企业集聚与水环境空间耦合关系, 以期为张家口地 区工业企业在空间上的合理布局与水环境的协调发展提供科学依据。

\section{1 研究方法与数据来源}

\section{1 研究区概况}

张家口市位于华北平原与内蒙古高原的过渡地带，包括坝上、坝下两大地貌单元。 北部坝上高原地区海拔高度在 $1400 \mathrm{~m}$ 左右, 地势平坦, 草原辽阔。南部坝下地区属低山 盆地, 洋河盆地和桑干河盆地分布其中。全区河流属于海河流域，南部有大青河上游的 3 条支流，中部有永定河及其支流桑干河和洋河，其中永定河流至官厅水库。北京密云 水库、官厅水库分别有 $53 \%$ 、90\%的水量从张家口市流人 ${ }^{[25]}$ 。

\section{2 数据来源}

根据 2017 年张家口市环统数据, 有排污工业企业 253 家。在分析指标选择上，考虑 到 $\mathrm{COD}$ 和 $\mathrm{NH}_{3}-\mathrm{N}$ 、总氮为最主要的水体污染物, 而总磷的排放量几近为零, 因此选择 $\mathrm{COD} 、 \mathrm{NH}_{3}-\mathrm{N}$ 、总氮作为表征指标来评价水污染分布情况。

\section{3 研究方法}

(1) 核密度分析法

核密度分析主要是根据核函数，将每个点或线要素拟合成平滑雉状面，中心位置的 核密度为整个窗口范围内的密度之和 ${ }^{[2]}$, 在大气污染物、水污染空间分布特征模拟中广 泛应用 ${ }^{[2728]}$ 。本文采用核密度分析将点的集聚特征表现在空间上 ${ }^{[29]}$, 计算公式为:

$$
f_{n}(x)=\frac{1}{n h} \sum_{i=1}^{n} k\left(x-x_{i}\right) / h
$$

式中: $h$ 是窗口带宽; $n$ 是窗口中的点数; $\left(x-x_{i}\right)$ 是从估计点 $x$ 到采样点 $x_{i}$ 的距离 $\left(\mathrm{km}^{2}\right) ; k(\cdot)$ 为核函数方程。 $f_{n}(x)$ 值越大, 核密度越高。

(2) 水污染物排放强度

水污染物排放强度以乡镇为基本单元，通过单位面积上每个污染企业排放的水污染 物数量来表征。计算公式如下:

$$
\begin{aligned}
C O D_{n} & =\sum_{i=1}^{n} C O D_{i} / A \\
N H_{3} N_{S} & =\sum_{i=1}^{n} N H_{3} N_{S i} / A \\
N_{S} & =\sum_{i=1}^{n} N_{S i} / A
\end{aligned}
$$

式中: $C O D_{n}$ 表示评价单元 $A$ 内的化学需氧量的排放强度 $\left(\mathrm{t} / \mathrm{km}^{2}\right) ; C O D_{i}$ 为第 $i$ 个企业的 污染物排放量 $(\mathrm{t}) ; \mathrm{NH}_{3} \mathrm{~N}_{S}$ 表示评价单元 $A$ 内的氨氮的排放强度 $\left(\mathrm{t} / \mathrm{km}^{2}\right) ; N H_{3} N \mathrm{~S}_{i}$ 表示第 $i$ 个企业的氨氮排放量 $(\mathrm{t}) ; N_{S}$ 表示评价单元 $A$ 内的总氮排放强度 $\left(\mathrm{t} / \mathrm{km}^{2}\right) ; N_{S i}$ 表示第 $i$ 个 企业的总氮排放量 $(\mathrm{t}) ; A$ 为评价单元的面积 $\left(\mathrm{km}^{2}\right)$ 。 
（3）单因子水质评价方法

在水环境质量评价方面, 依据《地表水环境质量标准》, 采用单因子评价法进行计 算，具体公式如下:

$$
W_{i}=M_{i} / N_{i}
$$

式中: $W_{i}$ 为水质指数; $M_{i}$ 为因子 $i$ 实测浓度 $; N_{i}$ 为 III类水标准中 $i$ 类浓度值。

\section{2 结果分析}

\section{1 排污工业企业污染物排放现状}

2017 年张家口市的工业总产值, $\mathrm{COD} 、 \mathrm{NH}_{3}-\mathrm{N}$ 、总磷的排放量均占所有 企业总量的 $90 \%$ 以上的 12 个行业（图 1)。 工业源 $\mathrm{COD} 、 \mathrm{NH}_{3}-\mathrm{N}$ 、总氮排放位居前 三的行业集中在农副食品加工、黑色金 属冶炼及压延加工、食品制造、煤炭开 采和选洗等四大行业。其中, 农副食品 加工业的 COD 排放量、 $\mathrm{NH}_{3}-\mathrm{N}$ 、总氮排 放量分别是 COD、 $\mathrm{NH}_{3}-\mathrm{N}$ 、总氮排放的 第一、第二、第二大行业，占所有行业 排放量的比例分别达到 $22.15 \%$ 、 $13.53 \%$ 、20.72\%；黑色金属冶炼及压延 加工业是 COD 排放的第二大行业，占所 有行业排放的 $14.01 \%$ ，但同时也是总氮

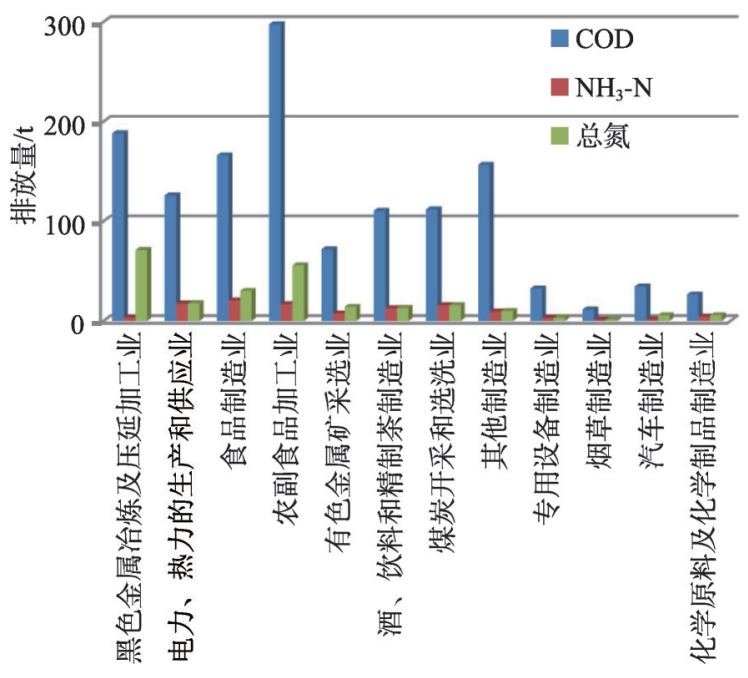

图 1 各行业工业总产值与水污染物排放对比图

Fig. 1 Comparison map of industrial output and pollutant discharge in different industries 排放的第一大行业，占所有行业排放的

$26.54 \%$ ；食品制造业是 $\mathrm{NH}_{3}-\mathrm{N}$ 排放的第一大行业，占所有行业排放的 $16.63 \%$, 但同时也 是 COD、总氮排放的第三大行业，分别占所有行业排放的 $12.35 \% 、 11.23 \%$; 煤炭开采和 选洗业是 $\mathrm{NH}_{3}-\mathrm{N}$ 排放的第三大行业，占所有行业排放的 $12.7 \%$, 但同时也是 COD 排放的 第五大行业、总氮排放的第四大行业，分别占所有行业排放的 $8.32 \% 、 5.88 \%$ 。

\section{2 排污工业企业空间集聚特征}

根据各行业工业总产值与水污染物排放耦合关系（图 2)，张家口烟草制造业为产值 贡献率高且污染物排放低的绿色产业。而农副食品加工业产值与其污染排放量的力矩差 最大，两者的匹配度低。产值贡献率高且污染物排放量大的三个行业，分别是黑色金属 冶炼及压延加工业, 电力、热力的生产和供应业, 食品制造业。产值贡献率较低且污染 物排放量较大有三个行业，分别为农副食品加工业，煤炭开采和选洗业，其他制造业。

坝上地区主要是食品制造业、农副食品加工业主要聚集区。酒、饮料和精制茶制造 业主要分布在溷鹿县、怀来县等坝下山间盆地。黑色金属冶炼及压延加工业主要分布在 中心城市，有色金属矿采选业主要分布在宣化区、赤城县等东部燕山山地，电力、热力 的生产和供应主要分布在怀来县, 煤炭开采和选洗业主要分布在蔚县, 与山西省毗邻。

采用核密度分布函数分析行业空间集聚程度（网格输出单元 $1 \mathrm{~km} \times 1 \mathrm{~km} ，$ 带宽 $10 \mathrm{~km}$ )。 


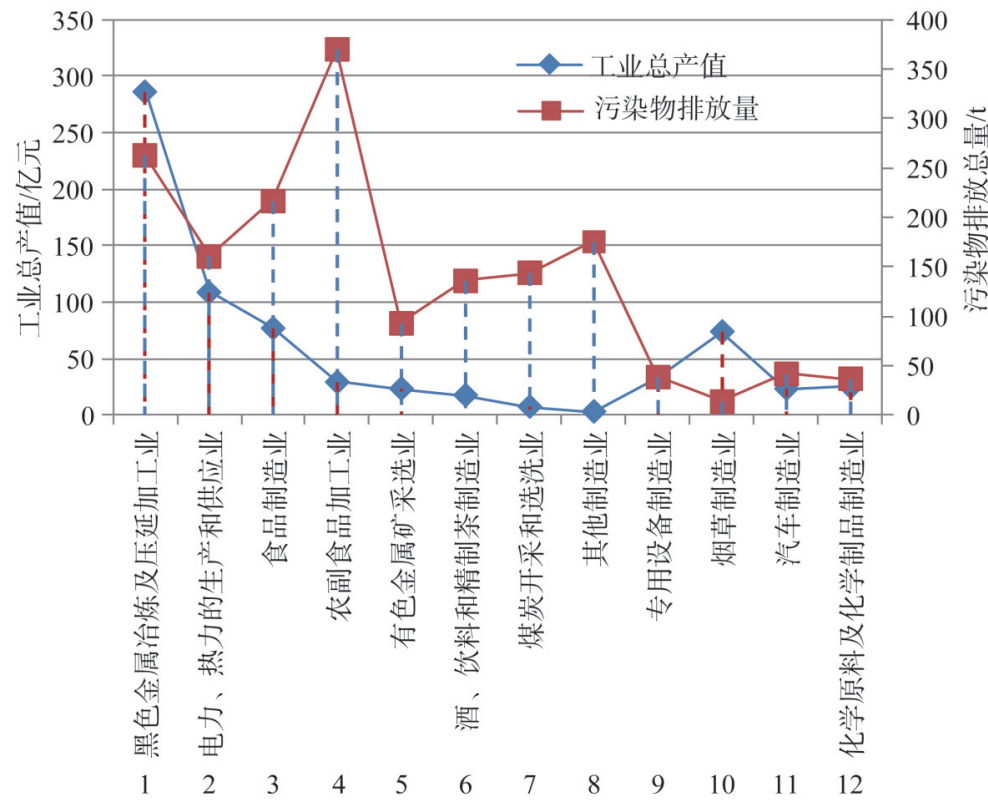

图 2 各行业工业总产值与水污染物排放耦合关系图

Fig. 2 The coupling map of industrial output value and pollutant discharge

从张家口地区污染密集型工业企业核密度图看 （图 3)，分行业企业空间集聚程度存在一定的空 间异质性，崇礼区、赤城县整体上几乎无污染密 集型企业分布。从行业的空间集聚程度看，污染 密集型企业主要沿洋河分布, 集中在万全区、怀 来县、张北县。

\section{3 典型流域的水质现状分析}

根据排污工业企业空间集聚特征可知，污染 企业主要沿流域分布。因此, 着重分析洋河、桑 干河、清水河流域的水质特征。2017年流域的水 质现状表明: 洋河流域的响水铺断面、八号桥断 面水质受到污染，为IV类水; 其余断面水质达标。

\section{4 水环境的空间分布特征}

张家口排污强度空间格局呈明显的不均衡状 态，并以宣化区、张北县、桥东区为核心呈逐级 递减趋势。COD 污染物排放强度大的乡镇主要集 中在宣化区、张北县、蔚县、万全区, $\mathrm{NH}_{3}-\mathrm{N}$ 污 染物排放强度大的乡镇主要集中在宣化区、宣化

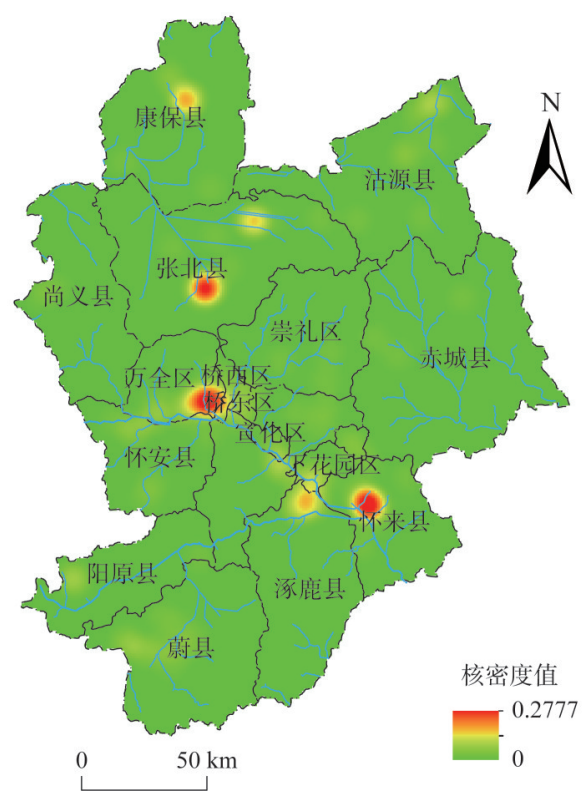

图 3 污染密集型工业企业核密度图

Fig. 3 Kernel density map for polluting manufacturing 县、张北县、桥东区。总氮污染物排放强度大的乡镇主要集中在宣化区、张北县。其 他乡镇排污强度均较小。其中, COD 的最大、最小排放强度分别为 $224.26 \mathrm{t} / \mathrm{km}^{2}$ 、 $0.012 \mathrm{t} / \mathrm{km}^{2}, \mathrm{NH}_{3}-\mathrm{N}$ 最大、最小排放强度分别为 $20.31 \mathrm{t} / \mathrm{km}^{2} 、 0.0019 \mathrm{t} / \mathrm{km}^{2}$ ，总氮最大、最 小排放强度分别为 $70.86 \mathrm{t} / \mathrm{km}^{2} 、 0.0019 \mathrm{t} / \mathrm{km}^{2}$ 。 


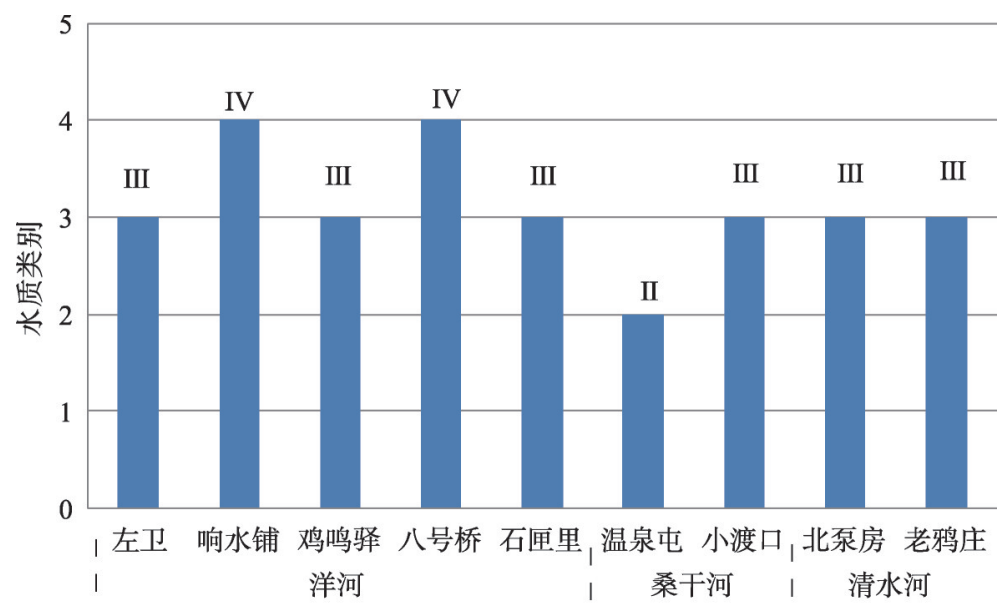

图 4 典型流域的水质现状

Fig. 4 Present situation of water quality in the typical watershed

\section{5 排污工业企业与水环境的空间耦合特征}

借助 ArcGIS 的自然断点法将产业集聚强度 （即核密度值）与污染物排放强度分为高值、低值 2 个等级, ArcGIS 的空间分析功能对产业集聚强 度图和污染物排放强度图进行空间叠置分析，根 据叠置的空间要素组合得到排污工业企业集聚与 污染的空间耦合关系，并将张家口地区分为产业 低集聚区一污染物低值区、产业低集聚区一污染 物高值区，产业高集聚区一污染物低值区、产业 高集聚区一污染物高值区四种类型（图6）。整体 上张家口排污工业企业集聚程度与水污染程度的 空间耦合效应明显，96.23\%（高集聚一污染高值 区、低集聚一污染低值区）的地区呈强度的空间 正向耦合作用。张家口地处内蒙地轴与燕山台褶 带构造单元的过渡带上, 煤矿、金矿、铁矿等矿 源层分布广泛。沿矿床分布的宣化、蔚县等区 域，伴生发展了许多传统工业产业，其企业空间 集聚和污染物高排放耦合效应显著，这些工业产 业多位于省级重点开发区。

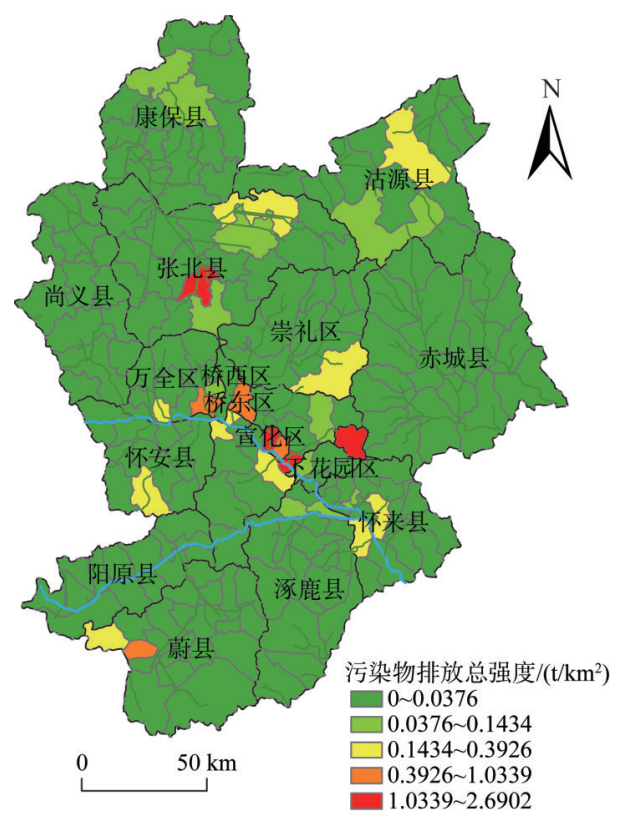

图 5 污染物总排放强度分布格局

Fig. 5 Distribution pattern of pollution emission intensity

高集聚一污染高值区属于排污企业密集且水污染排放高值的区域，该类区域污染企 业集聚程度与污染物排放呈现强烈的空间正相关性，该类区域总面积为 $147.45 \mathrm{~km}^{2}$, 占 比 $0.40 \%$, 主要分布在张北县、宣化区、蔚县。主要是农副食品加工业、其他制造业、 煤炭开采和选洗业的集中分布区，这几类产业排放的污染物对当地水环境造成较大压 力。未来污染物排放管控方向为提高环境准人标准，加强污染物的集中治理水平，实行 严格的排污管控。对于未达标区，执行特别排放限值，制定水污染物的消减方案。针对 该区域重点发展行业提出水污染物排放约束性和建议性准人指标。同时，充分利用现有 
产业集聚的空间布局优势，向低污染一高集聚方 向发展。

低集聚一污染高值区属于企业分散但水污 染排放值较高的区域。该类型区域面积为 $253.68 \mathrm{~km}^{2}$, 占比 $0.69 \%$, 主要分布在蔚县, 宣 化区。该区是重点污染防治区, 未来污染物排放 管控方向为提高环境准人标准, 实行严格的排污 管控，对于水质未达标区域，执行水污染物特别 排放限值, 制定水污染物的消减比例, 确保企业 污染物达标排放。针对该区域重点发展行业提出 水污染物排放约束性和建议性准人指标, 落实建 设项目人园, 倒逼零散分布的企业人园区, 加强 污染物的集中治理水平，提高企业的集聚度，向 低污染一高集聚方向发展。

低集聚一污染低值区为污染密集型企业分布 分散, 污染排放值较低的区域。该类区分布广 泛，总面积为 $35138.45 \mathrm{~km}^{2}$, 占总面积的 $95.83 \%$ 。坝上区域多为水源涵养与水土保持生态

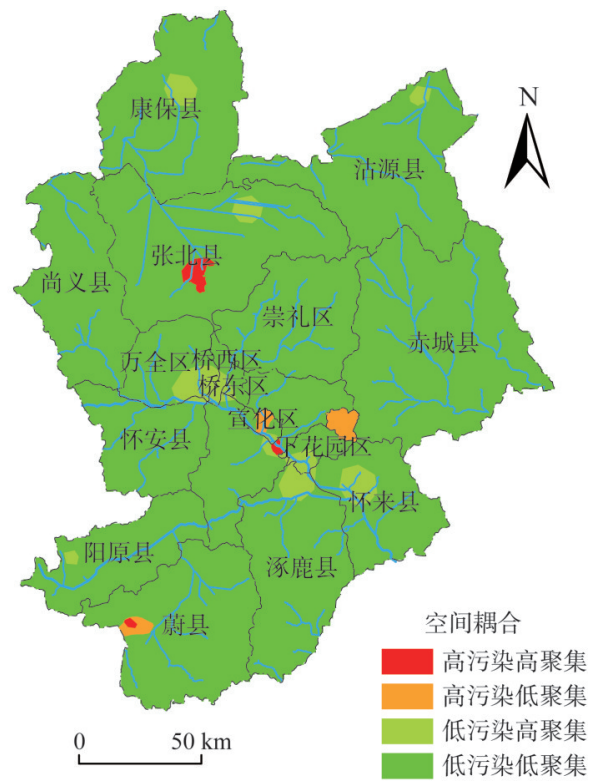

图 6 排污企业集聚与水环境污染空间耦合图 Fig. 6 The coupling map of industrial cluster and water environment pollution 功能区、草原与农业生产生态功能区、森林与草原水源涵养生态功能区，属于限制开发 或禁止开发区域, 对水环境要求较高, 严格按照现有相关规定执行污染物排放管控要 求，禁止损害生态服务功能的开发建设活动。限制污染型企业，落实建设项目人园，强 化环境准人条件，继续保持并提升环境质量水平。

高集聚一污染低值区是密集型企业集中且污染排放值较低的地区。该类区域主要分布 在怀来县、万全区、涿鹿县等 14 个区县。此类区域分布面积 $1127.30 \mathrm{~km}^{2}$, 占比 $3.07 \%$ 。充 分利用企业的集聚优势，该类区域企业集聚度高，污染治理水平较高，对已有污染企业仍 应执行严格的排污管控，提高企业环境准入标准，继续保持并提升环境质量水平。

\section{3 结论与讨论}

\section{1 结论}

文章以张家口地区为研究区，分析污染工业企业空间集聚格局，及其与水环境的耦 合关系。

（1）黑色金属冶炼及压延加工业，电力、热力的生产和供应业，食品制造业三个行业 的产值贡献率高且污染物排放量大。农副食品加工业，有色金属矿采选业，其他制造业三 个行业的产值贡献率较低且污染物排放量较大。

（2）洋河流域的响水铺断面、八号桥断面水质受到污染，其余断面水质达标。工业 企业分行业的空间集聚差异性明显。崇礼区、赤城县整体上几乎无污染密集型企业分 布。污染密集型企业主要沿洋河流域集中分布在万全区、怀来县、张北县。COD污染物 排放强度大的区域主要集中在宣化区、张北县、万全区, $\mathrm{NH}_{3}-\mathrm{N}$ 污染物排放强度大的区 域主要集中在宣化区、张北县、桥东区。总氮污染物排放强度大的区域主要集中在宣化 
区、张北县。其中, $\mathrm{COD} 、 \mathrm{NH}_{3}-\mathrm{N}$ 、总氮最大排放强度分别为 $224.26 \mathrm{t} / \mathrm{km}^{2} 、 20.31 \mathrm{t} / \mathrm{km}^{2}$ 、 $70.86 \mathrm{t} / \mathrm{km}^{2}$ ，最小排放强度分别为 $0.012 \mathrm{t} / \mathrm{km}^{2} 、 0.0019 \mathrm{t} / \mathrm{km}^{2} 、 0.0019 \mathrm{t} / \mathrm{km}^{2}$ 。

（3）张家口排污工业企业集聚程度与水环境污染程度的空间耦合效应明显，96.23\% （高集聚一污染高值区、低集聚一污染低值区）的地区呈强度的空间正向耦合作用。高集 一污染高值区、低集聚一污染高值区、低集聚一污染低值区、高集聚一污染低值区面积 占比分别为 $0.40 \% 、 0.69 \%$ 、 $95.83 \% 、 3.07 \%$ 。对四种空间耦合状态针对性提出未来污染 物排放管控方向，以期为政府部门准确锁定治理区提供决策依据。

\section{2 讨论}

从张家口地区工业企业集聚程度与水环境污染程度的空间耦合结果看，95.83\%为低 集聚一污染低值区、0.40\%为高集聚一污染高值区，空间耦合格局特征明显。日趋合理的 空间耦合格局与张家口近年的环境政策的实施有很大关系。近年来，张家口市政府着力 调整产业结构, 改造升级传统产业, 推出 “雷霆行动”, 整治矿山、淘汰落后产能, 全面 实施污染源日常监察 “双随机” 制度等措施。越来越多的企业向工业园区集聚，政府在 推进企业集聚的同时，应促进产业技术改进提升生产效能，加强污染物的集中治理水 平。无论是传统制造业还是新兴产业都应加强污染物治理水平, 减少污染物排放强度, 达到节能减排的效果, 进而缓解环境污染。建议强化工业生产环境风险控制, 建立可精 准溯源的排污监测体系, 研究跨区排污配额及共治对策。同时, 以申办冬奥会为契机, 充分发挥资源特色、生态优势，重点发展生态旅游产业和绿色农业产业，打造绿色产业 集聚区，逐步形成生态北翼、京张高新产业带和特色南翼的工业产业格局。通过产业集 聚和工业园区建设，大力调整张家口市产业布局。以生态农业园区和区域化特色产业带 为载体, 调整农业区域布局。

值得注意的是张家口坝上六县属于国家重点生态功能区，应严格实施并遵守国家重 点生态功能区产业负面清单，严把项目准人关。目前，由生态环境部主导的“三线一 单” 编制工作已在全国全面启动，张家口市生态保护红线、环境质量底线、资源利用上 线和生态环境准人清单的科学确定，将有效推进生态环境保护精细化管控。

在污染物排放强度测算方面，通过单位面积上各污染企业的污染物排放量来表征，评 价结果受行政单元面积的影响较大, 难免存在不合理的地方。今后, 污染物排放强度的计 算可通过探讨每单位产值的污染物排放量来表征。由于受资料限制仅对张家口 2017 年的 工业企业集聚与水环境空间耦合特征进行研究，今后还可以探讨其动态变化特征。

\section{参考文献(References):}

[1] POTER M E. The Competitive Advantage of Nations. New York: The Free Press, 1990.

[2] DURANTON G, PUGA D. Micro-foundations of urban agglomeration economies. Handbook of Regional and Urban Economics, 2004, 4(11): 2063-2117.

[3] ZHANG Y, JIANG D. FDI, industrial agglomeration and technology progress: Evidence from Chinese manufacturing industries. Journal of Finance and Economics, 2008, 34(1): 72-82.

[4] 毛熙彦, 刘颖, 贺灿飞. 中国资源性产业空间演变特征. 自然资源学报, 2015, 30(8): 1332-1342. [MAO X Y, LIU Y, HE C F. Spatial pattern dynamics of resource-based industry in China. Journal of Natural Resources, 2015, 30(8): 1332-1342.]

[5] 周㑆, 王强, 㚞杰. 经济集聚对区域水污染物排放的影响及溢出效应. 自然资源学报, 2019, 34(7): 483-1495. [ZHOU K, WANG Q, FAN J. Impact of economic agglomeration on regional water pollutant emissions and its spillover effects. Journal of Natural Resources, 2019, 34(7): 483-1495.]

[6] 周㑆. 中国环境污染的时空差异与集聚特征. 地理科学, 2016, 36(7): 989-997. [ZHOU K. Spatial-temporal differences 
and cluster features of environmental pollution in China. Scientia Geographica Sinica, 2016, 36(7): 989-997.]

[7] 贺灿飞, 任永欢, 李蕴雄. 产品结构演化的跨界效应研究: 基于中国地级市出口产品的实证分析. 地理科学, 2016, 36 (11): 1605-1613. [HE C F, REN Y H, LI Y X. The mechanism of cross-boundary product evolution in China: An empirical analysis based on export product of prefecture-level Cities. Scientia Geographica Sinica, 2016, 36(11): 1605-1613.]

[8] JIANG G, MA W, DING Y Z, et al. Agglomeration or dispersion? Industrial land-use pattern and its impacts in rural areas from China's township and village enterprises perspective. Journal of Cleaner Production, 2017, 166(10): 207-219.

[9] 尹鹏, 李诚固. 环渤海 “C 型” 经济区经济格局的空间演变研究. 地理科学, 2015, 35(5): 537-543. [YIN P, LI C G. Spatial evolution of economic pattern in spatial in C-typed. Scientia Geographica Sinica, 2015, 35(5): 537-543.]

[10] CONG H, ZOU D. The research on the mechanism and spatial temporal differentiation of the coupling coordination development based on industrial cluster agglomeration. Cluster Computing, 2017, 20(1): 195-213.

[11] 张姗姗, 张否, 张落成, 等. 苏南太湖流域污染企业集聚与水环境污染空间耦合关系. 地理科学, 2018, 38(6): 954962. [ZHANG S S, ZHANG L, ZHANG L C, et al. Coupling relationship between polluting industrial agglomeration and water environment pollution in southern Jiangsu of Taihu Lake Basin. Scientia Geographica Sinica, 2018, 38(6): 954-962.]

[12] 高爽, 魏也华, 陈雯, 等. 发达地区制造业集聚和水污染的空间关联: 以无锡市区为例. 地理研究, 2011, 30(5): 902912. [GAO S, WEI Y H, CHEN W, et al. Study on special-correlation between water pollution and industrial agglomeration in the developed region of China: A case study of Wuxi city. Geographical Research, 2011, 30(5): 902-912.]

[13] 朱华晟, 王缉慈. 论柔性生产与产业集聚. 世界地理研究, 2001, 10(4): 39-46. [ZHU H S, WANG J C. Flexible production and industrial agglomeration. World Regional Studies, 2001, 10(4): 39-46.]

[14] MARTIN A, HANS L. Agglomeration and productivity: Evidence from firm level data. The Annals of Regional Science, 2011, 46(3): 601-620.

[15] 武翠. 工业经济增长背景下制造业集聚对我国工业污染的影响研究. 南京: 南京信息工程大学, 2015. [WU C. Study on the effect of manufacturing industrial cluster on industrial pollution in the context of industrial economic development. Nanjing: Nanjing University of Information Science and Technology, 2015.]

[16] 沈静, 向澄, 柳意云. 广东省污染密集型产业转移机制: 基于 2000-2009年面板数据模型的实证. 地理研究, 2012, 31(2): 357-368. [SHEN J, XIANG C, LIU Y Y. The mechanism of pollution: Intensive industry relocation in Guangdong province, 2000-2009. Geographical Research, 2012, 31(2): 357-368.]

[17] PEYMAN B, FRITJOF F, ABOLFAZL S, et al. Environmental Science and Pollution Research. Springer Berlin Heidelberg, 2015.

[18] MONRIKI H, TOHRU N. Trans-boundary pollution transmission and regional agglomeration effects. Papers in Regional Science, 2006, 85(1): 99-120.

[19] EMEL T, LAURA S, ILHAN T. A systematic evaluation of agglomeration of Ag and $\mathrm{TiO}_{2}$ nanoparticles under freshwater relevant conditions. Environmental Pollution, 2014, 193(10): 37-44.

[20] 邹继武. 我国制造业集聚对环境污染的影响研究: 基于空间计量视角. 湘潭: 湖南科技大学, 2016. [ZOU J W. The influence of Chinese manufacturing industries' agglomeration to the environment pollution: Based on the view of spatial economitric. Xiangtan: Hunan University of Science and Technology, 2016.]

[21] 王艳华, 苗长虹, 胡志强, 等. 专业化、多样性与中国省域工业污染排放的关系. 自然资源学报, 2019, 34(3): 586599. [WANG Y H, MIAO C H, HU Z Q, et al. Specialization, diversity and their impacts on China's provincial industrial pollution emissions. Journal of Natural Resources, 2019, 34(3): 586-599.]

[22] 曾勇, 王西琴. 浙江西苕溪水环境容量模型与参数灵敏度分析. 中国环境科学, 2010, 30(12): 1627-1632. [ZENG Y, WANG X Q. Water environmental capacity model and its parameters sensitivity analysis for Xitiaoxi River in Zhejiang province, China. China Environmental Science, 2010, 30(12): 1627-1632.]

[23] 李瑞芳. 我国制造业集聚与大气污染关系的实证分析. 河南: 河南师范大学, 2012. [LI R F. Our country manufacturing industry cluster and the empirical analysis of the relationship between atmospheric pollution. Henan: Henan Normal University, 2012.]

[24] 赵海霞, 王梅, 段学军. 水环境容量约束下的太湖流域产业集聚空间优化. 中国环境科学, 2012, 32(8): 1530-1536. [ZHAO H X, WANG M, DUAN X J. Spatial optimization of industrial clustering under the constraint of water environmental capacity in Taihu Lake Basin. China Environmental Science, 2012, 32(8): 1530-1536.]

[25] SONG C, YAN J J, SHA J H, et al. Dynamic modeling application for simulating optimal policies on water conservation 
in Zhangjiakou city, China. Journal of Cleaner Production, 2018, 201: 111-122.

[26] 陈晨, 程林, 修春亮. 沈阳市中心城区交通网络中心性及其与第三产业经济密度空间分布的关系. 地理科学进展, 2013, 32(11): 1612-1621. [CHEN C, CHENG L, XIU C L. Distribution of centrality of traffic network and its relationship with economic density of tertiary industry in Shenyang. Progress in Geography, 2013, 32(11): 1612-1621.]

[27] 刘华军,杜广杰. 中国城市大气污染的空间格局与分布动态演进: 基于 161 个城市 AQI 及 6 种分项污染物的实证. 经济地理, 2016, 36(10): 33-38. [LIU H J, DU G J. Spatial pattern and distributional dynamics of urban air pollution in China. Economic Geography, 2016, 36(10): 33-38.]

[28] ZHANG Z M, WANG X Y, ZHANG Y, et al. The over polluted water quality assessment of Weihe River based on Kernel Density Estimation. Procedia Environmental Sciences, 2012, 13: 1271-1282.

[29] 祝汉收, 刘春霞, 李月臣. 重庆市战略性新兴产业空间集聚测度及时空演变分析. 重庆师范大学学报: 自然科学版, 2018, 35(5): 63-70. [ZHU H S, LIU C X, LI Y C. The geographic agglomeration of Chongqing's strategic emerging industries based on GIS and its relationship with GDP. Journal of Chongqing Normal University: Natural Science, 2018, 35(5): 63-70.]

\title{
The coupling characteristics between polluting industrial agglomeration and water pollution discharge in Zhangjiakou
}

\author{
YU Hui ${ }^{1}$, ZHONG Jia ${ }^{1,2}$, LIU Shao-quan ${ }^{1}$, YANG De-wei ${ }^{3,4}$ \\ (1. Institute of Mountain Hazards and Environment, CAS, Chengdu 610041, China; 2. University of Chinese \\ Academy of Sciences, Beijing 100049, China; 3. School of Geographical Sciences, Southwest University, \\ Chongqing 400715, China; 4. Key Lab of Urban Environment and Health, Institute of Urban Environment, \\ CAS, Xiamen 361021, Fujian, China)
}

\begin{abstract}
This research examines the spatial agglomeration characteristics of industrial enterprises and their spatial coupling characteristics with water pollution discharge in Zhangjiakou by the method of kernel density analysis and pollutant discharge intensity, based on the environmental statistical data of industrial pollution sources in the study area. The results show that: (1) There is a certain spatial heterogeneity in the spatial concentration of industrial enterprises, and there is almost no pollution-intensive enterprise in Chongli and Chicheng counties. Pollution- intensive enterprises mainly distribute in the urban ecological construction functional areas along the Yanghe River. (2) Agricultural and sideline food processing industry, ferrous metal smelting and calendaring processing industry, food manufacturing industry, coal mining and washing industry are the four major industries with the largest discharge of water pollutants such as $\mathrm{COD}, \mathrm{NH}_{3}-\mathrm{N}$ and total nitrogen. (3) The spatial positive coupling effect between the degree of industrial enterprise agglomeration and the degree of water pollution is obvious, and $96.23 \%$ of the areas show a strong positive coupling. The proportion of high pollution value-high concentration area was $0.40 \%$. In view of the four spatial coupling types, the future direction of pollutant emission control is proposed in order to provide the decision-making basis for the government to accurately lock the control area.
\end{abstract}

Keywords: industrial cluster; water pollutant characteristics; spatial coupling 